\title{
Curcumin reverses the epithelial-mesenchymal transition of pancreatic cancer cells by inhibiting the Hedgehog signaling pathway
}

\author{
XIAO-DONG SUN ${ }^{1}$, XING-E LIU ${ }^{2}$ and DONG-SHENG HUANG ${ }^{1}$ \\ ${ }^{1}$ Department of Hepatopancreatobiliary Surgery, Zhejiang Provincial People's Hospital, Hangzhou, Zhejiang 310014; \\ ${ }^{2}$ Department of Medical Oncology, Zhejiang Hospital, Hangzhou, Zhejiang 310013, P.R. China
}

Received January 11, 2013; Accepted March 8, 2013

DOI: 10.3892/or.2013.2385

\begin{abstract}
Curcumin, a phenolic compound extracted from Zingiberaceae turmeric, has strong anti-inflammatory, antioxidant and antitumor properties. However, the anticarcinogenic mechanism of curcumin has yet to be fully elucidated. Epithelial-mesenchymal transition (EMT) induced by transforming growth factor- $\beta 1$ (TGF- $\beta 1$ ) is involved in the promotion of tumor invasion and metastasis, and is closely related to the drug resistance of tumor cells. The abnormal activation of Hedgehog signaling also plays an important role in tumorigenesis and metastasis. In order to investigate whether curcumin can reverse the TGF- $\beta 1$-stimulated EMT of pancreatic cancer PANC-1 cells, and its possible mechanism, the pancreatic cancer cell line PANC-1 was stimulated with TGF- $\beta 1(5 \mathrm{ng} / \mathrm{ml})$ for 7 days to induce formation of EMT, and the TGF- $\beta 1$-stimulated PANC-1 cells were treated with different concentrations of curcumin $(10,20$ and $30 \mu \mathrm{mol} / \mathrm{ml})$ for $48 \mathrm{~h}$. The growth inhibition rate of the cells was measured by MTT assay, apoptosis was detected by flow cytometry, the expression levels of Shh, GLI1, E-cadherin and vimentin were detected by western blot analysis, and cell invasion and migration ability were examined by Transwell cell invasion assay and wound healing assay. Following stimulation with TGF- $\beta 1$, the expression levels of Shh, GLI1 and vimentin in the TGF- $\beta 1-$ stimulated group were significantly increased, compared with those in the control group $(\mathrm{P}<0.01$, respectively). The expression levels of E-cadherin in the TGF- $\beta 1$-stimulated group were significantly decreased, compared with those in the control group $(\mathrm{P}<0.01)$. The TGF- $\beta 1$-stimulated PANC-1 cells were treated with curcumin and the results showed that curcumin significantly inhibited TGF- $\beta 1$-stimulated PANC-1 cell proliferation and induced apoptosis, compared with other groups $(\mathrm{P}<0.01)$, and the expression levels of Shh, GLI1 and
\end{abstract}

Correspondence to: Dr Xing-E Liu, Department of Medical Oncology, Zhejiang Hospital, 12 Linyin Road, Hangzhou, Zhejiang 310013, P.R. China

E-mail: xingel@sohu.com

Key words: curcumin, epithelial-mesenchymal transition, pancreatic cancer, transforming growth factor- $\beta 1$, Hedgehog vimentin in the curcumin-treated group were significantly decreased compared with those in the control group $(\mathrm{P}<0.01$, respectively). The expression level of E-cadherin in the curcumin-treated group was significantly increased compared with that in the control group $(\mathrm{P}<0.01)$. Cell invasion in the curcumin-treated group $(30 \mu \mathrm{mol} / \mathrm{ml})$ was significantly decreased compared with that in the control group $(\mathrm{P}<0.01)$. The scratch wounds in the curcumin-treated group healed slower compared with those in the control group $(\mathrm{P}<0.01)$. Curcumin significantly inhibited the invasion and migration of TGF- $\beta 1$-stimulated PANC- 1 cells. These results indicate that curcumin can inhibit the proliferation of TGF- $\beta 1$-stimulated PANC-1 cells, it can induce apoptosis, and reverse the EMT. The possible underlying molecular mechanisms are through inhibition of the Shh-GLI1 signaling pathway.

\section{Introduction}

Curcumin is a phenolic compound that is extracted from Zingiberaceae turmeric and has strong anti-inflammatory, antioxidant and antimutation properties. Recent studies have shown that curcumin can inhibit the growth, invasion and metastasis of a variety of tumor cells, it can induce apoptosis through a variety of mechanisms, and can improve the sensitivity of tumor cells to chemotherapeutic drugs and radiotherapy $(1,2)$.

Transforming growth factor- $\beta 1$ (TGF- $\beta 1)$ can induce tumor cell epithelial-mesenchymal transition (EMT) $(3,4)$. EMT is involved in tumorigenesis and development and plays an important role in the promotion of tumor invasion and metastasis and it is also closely related to drug resistance of tumor cells $(5,6)$. In some particular physiological or pathological conditions, the epithelial cells lose their polarity, convert into interstitial cells and are able to move freely in the cell matrix. The most important characteristic of EMT cells is the reduction or loss of the epithelial marker E-cadherin $(7,8)$ and the induction of the mesenchymal markers such as fibronectin protein, vimentin.

Studies have shown that the abnormal activation of Hedgehog (Hh) signaling plays a significant role in tumorigenesis and metastasis $(9,10)$. The Hh signaling pathway is a highly conserved signaling pathway, composed of the signal molecule Hh, two membrane receptors patched (Ptch) and smoothened 
(Smo), and the downstream nuclear transcription factor Gli. GIi proteins play a key role in the Hh signaling pathway. If having no ligands, Ptch binds with Smo and inhibits the function of Smo. When Hh presented, Hh ligand binds to its receptor Ptch, Smo is released and activated and, ultimately, the entire length of Gli transported to the nucleus and activated the transcription of target genes. Gli target genes are involved in tumor cell growth, apoptosis, metastasis, EMT and neovascularization (11).

In the present study, we stimulated the pancreatic cancer PANC- 1 cells with TGF- $\beta 1$, we treated the cells with different concentrations of curcumin and then detected the proliferation and apoptosis of each group of cells. We analyzed the expression levels of Shh, GLI1, E-cadherin and vimentin and evaluated the invasion and migration ability of each group of cells in vitro. The aim of the present study was to investigate whether curcumin can reverse the TGF- $\beta 1$-induced EMT of pancreatic cancer PANC-1 cells and to explore its possible mechanism.

\section{Materials and methods}

Cell lines and reagents. Pancreatic cancer PANC-1 cells were purchased from the Shanghai Cell Bank of the Chinese Academy of Sciences (Shanghai, China). Antibodies of rabbit anti-human Shh, GLI1, vimentin and E-cadherin were purchased from Cell Signaling Technology (Beverly, MA, USA). Mouse anti-rabbit secondary antibody was obtained from Beijing Zhongshan Golden Bridge Biotechnology Co., Ltd (Beijing, China). Annexin V/PI apoptosis detection kit was purchased from Multisciences Biotech Co., Ltd. (Hangzhou, China). DMEM and fetal bovine serum were purchased from Gibco (Grand Island, NY, USA). Curcumin and MTT were purchased from Sigma-Aldrich (Irvine, CA, USA). TGF- $\beta 1$ was purchased from R\&D Systems China Co., Ltd. (Shanghai, China). BD Matrigel ${ }^{\mathrm{TM}}$ Matrix basement membrane was purchased from BD Biosciences (Franklin Lakes, NJ, USA). Transwell insert $(8 \mu \mathrm{m})$ was purchased from Corning Incorporated (Corning, NY, USA).

Cell treatment. The pancreatic cancer cell line PANC-1 was grown in complete Dulbecco's modified Eagle's medium (DMEM) supplemented with $10 \%$ fetal bovine serum (FBS), $100 \mathrm{U} / \mathrm{ml}$ penicillin and streptomycin in $5 \% \mathrm{CO}_{2}$ at $37^{\circ}$. Cells were changed for fresh medium every 3 days. Cells were cocultured with TGF- $\beta 1(5 \mathrm{ng} / \mathrm{ml})$ for 7 days. Then, the TGF- $\beta 1$ stimulated pancreatic cancer cells were treated with different concentrations of curcumin $(10,20$ and $30 \mu \mathrm{mol} / \mathrm{ml})$ for $48 \mathrm{~h}$.

Cell proliferation assay (MTT). MTT was used to investigate the cellular growth inhibition rate. Following digestion with $0.25 \%$ trypsin, $1 \times 10^{4} \mathrm{TGF}-\beta 1$-stimulated pancreatic cancer cells were seeded in a 96 -well plate and allowed to adhere to the plate for $24 \mathrm{~h}$ at $37^{\circ} \mathrm{C}$. The cells were then divided into the control group and the curcumin-treated group (10, 20 and $30 \mu \mathrm{mol} / \mathrm{ml}$ ) and were treated for $48 \mathrm{~h}$. Thereafter, the cells in 96-well plates were centrifuged at $500 \mathrm{x}$ g for $3 \mathrm{~min}$, with $100 \mu \mathrm{l}$ supernatant in each well removed. Then, $10 \mu \mathrm{l}(5 \mathrm{mg} / \mathrm{ml})$ MTT in PBS was added to each well and the microtiter plates were incubated for an additional $4 \mathrm{~h}$ at $37^{\circ} \mathrm{C}$. DMSO $(100 \mu \mathrm{l})$ was then added to each well and OD570 value was detected with enzyme-labeled immunoassay instrument after shaking for $10 \mathrm{~min}$. The growth inhibition rate was calculated as follows: Inhibition rate $=\left(1-\mathrm{A}_{\text {treatment group }} / \mathrm{A}_{\text {control group }}\right) \times 100 \%$.

Cell apoptosis assay by flow cytometry. Cell apoptosis was investigated with the Annexin V-FITC apoptosis detection kit according to the corresponding protocols: $1 \times 10^{5} \mathrm{TGF}-\beta 1-$ stimulated pancreatic cancer cells were seeded in 6-well plates for $24 \mathrm{~h}$ at $37^{\circ} \mathrm{C}$. Then, the cells were divided into the control and the curcumin-treated group $(10,20$ and $30 \mu \mathrm{mol} / \mathrm{ml})$. Forty-eight hours later, cells in 6-well plates were collected and centrifuged at $800 \mathrm{x} \mathrm{g}$ for $5 \mathrm{~min}$. After adding buffer solution $(50 \mu \mathrm{l})$, V-FITC (5 $\mu \mathrm{l})$ and PI (10 $\mu \mathrm{l})$ for $5 \mathrm{~min}$, cells were transferred for flow cytometry assay.

Western blot analysis of Shh, GLII, vimentin and E-cadherin. After PANC-1 cells were cocultured with TGF- $\beta 1(5 \mathrm{ng} / \mathrm{ml})$ for 7 days, the expression levels of Shh, GLI1, vimentin and E-cadherin were detected by western blot analysis.

For western blot analysis, we prepared separation and spacer gels. Cells in the above groups were collected separately and total proteins in each group were extracted with the one-shot method. After mixing with $4 \mathrm{X}$ loading buffer, boiling for $5 \mathrm{~min}$, and centrifuging at 12,000 rpm for $3 \mathrm{~min}, 20 \mu \mathrm{l}$ of the resulting sample was used for SDS-PAGE analysis at $100 \mathrm{~V}$. When the separation step was completed, the gel was washed once with Millipore $\mathrm{H}_{2} \mathrm{O}$, electroblotted onto transfer membranes at $100 \mathrm{~V}$ for $2 \mathrm{~h}$, and then blocked with blocking reagent for $2 \mathrm{~h}$. The blots were incubated with corresponding primary antibodies for $24 \mathrm{~h}$. After washing four times (10 min each time) with Tris-buffered saline with Tween-20 (TBST), the membranes were incubated $1 \mathrm{~h}$ with secondary antibodies conjugated with horseradish peroxidase. The membranes were again washed four times (10 min each time) with TBST and incubated with ECL. Band Leader software was used for densitometry analysis of protein bands with GAPDH as internal control.

Subsequently, the TGF- $\beta 1$-stimulated pancreatic cancer PANC-1 cells were treated with curcumin $(30 \mu \mathrm{mol} / \mathrm{ml})$ for $48 \mathrm{~h}$. The expression levels of Shh, GLI1, vimentin and E-cadherin were also detected by western blot analysis, as described above.

Transwell cell invasion assay. Transwell chambers were placed in a 24-well plate. Matrigel was mixed with serum-free DMEM (1:3). Each small chamber was supplemented with $30 \mu \mathrm{l}$ of the Matrigel mixture, and then placed at $37^{\circ} \mathrm{C}$ for $30 \mathrm{~min}$. Then, $30 \mu \mathrm{l}$ serum-free DMEM containing $0.1 \%$ BSA was added to each chamber. Cells were then divided into the TGF- $\beta 1$-stimulated PANC-1 control group and the curcumintreated group $(30 \mu \mathrm{mol} / \mathrm{ml})$. Cells of each group $\left(3 \times 10^{4}\right)$ were resuspended in $300 \mu \mathrm{l}$ serum-free DMEM with $0.1 \%$ BSA and seeded in the transwell upper chamber. DMEM $(600 \mu \mathrm{l})$ containing $10 \%$ FBS was added to the lower chamber of the transwell. The cells were then incubated at $37^{\circ} \mathrm{C}, 5 \% \mathrm{CO}_{2}$ for $48 \mathrm{~h}$, the culture medium was absorbed and the cells of the microporous membranes were gently wiped off with a cotton swab; the invaded cells of the lower surface of the microporous membrane were retained in ice methanol for $1 \mathrm{~min}$ and $\mathrm{H} \& \mathrm{E}$ stained. The invading cells were counted in five randomly selected high magnification fields (x200). The experiment was repeated 5 times. 
A

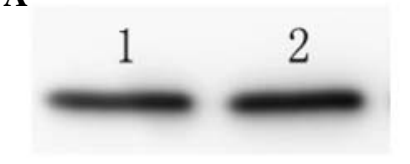

C

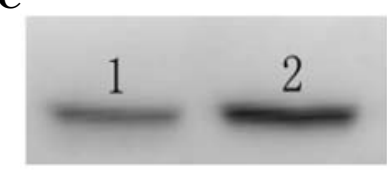

$\mathbf{E}$

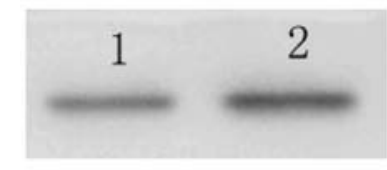

B

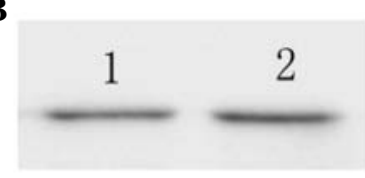

D

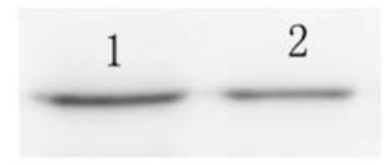

Table I. Growth inhibition rates of TGF- $\beta 1$-stimulated PANC-1 cells treated with curcumin detected by MTT $(\%$, mean \pm SD).

Group

Growth inhibition rate

Control group

0

Curcumin $(10 \mu \mathrm{mol} / \mathrm{ml})^{\mathrm{a}}$

$13.60 \pm 3.39$

Curcumin $(20 \mu \mathrm{mol} / \mathrm{ml})^{\mathrm{a}, \mathrm{b}}$

$17.43 \pm 3.70$

Curcumin $(30 \mu \mathrm{mol} / \mathrm{ml})^{\mathrm{a}, \mathrm{b}, \mathrm{c}}$

$62.18 \pm 6.87$

${ }^{\mathrm{a}} \mathrm{P}<0.01$ vs. control group; ${ }^{\mathrm{b}} \mathrm{P}<0.01$ vs. $10 \mu \mathrm{mol} / \mathrm{ml}$ curcumin group; ${ }^{\mathrm{c}} \mathrm{P}<0.01$ vs. 10 and $20 \mu \mathrm{mol} / \mathrm{ml}$ curcumin group.

explore whether TGF- $\beta 1$ induces the EMT of PANC-1 cells through activation of the Hh signaling, the expression levels of Shh, GLI1, E-cadherin and vimentin in TGF- $\beta 1$-stimulated PANC-1 cells were detected by western blot analysis.

Taking GAPDH as internal control, the results were obtained by semi-quantitative analysis of the gray scales of bands using Band Leader software. The results demonstrated that the expression levels of Shh and GLI1 in the TGF- $\beta 1$ stimulated group were significantly increased, compared with those in the control group $(\mathrm{t}=7.30, \mathrm{P}<0.01 ; \mathrm{t}=9.12$, $\mathrm{P}<0.01$, respectively). The expression level of E-cadherin in the TGF- $\beta 1$-stimulated group was significantly decreased, compared with that in the control group $(t=7.89, \mathrm{P}<0.01)$, and the expression level of vimentin in the TGF- $\beta 1$-stimulated group was also significantly elevated, compared with that in the control group $(\mathrm{t}=8.15, \mathrm{P}<0.01)$. These results suggest that the TGF- $\beta 1$-stimulated PANC- 1 cells are able to induce activation of the Hh signaling pathway and the EMT of PANC-1 cells, as shown in Fig. 1.

Curcumin inhibits proliferation and induces apoptosis of TGF- $\beta 1$-stimulated PANC-1 cells. TGF- $\beta 1$ can induce pancreatic cancer PANC-1 cell EMT. Our experimental results also suggest that following stimulation with TGF- $\beta 1$, the proliferation, invasiveness and migration ability of PANC-1 cells increased and the cell morphology changed, suggesting the occurrence of EMT.

Curcumin can inhibit the growth of various tumor cells through a variety of mechanisms and it can induce apoptosis. In order to verify the role of curcumin in TGF- $\beta 1$-stimulated PANC-1 cells, we treated the cells with different concentrations of curcumin $(10,20$ and $30 \mu \mathrm{mol} / \mathrm{ml})$ for $48 \mathrm{~h}$.

The results indicated that as the curcumin concentration increased, its proliferation inhibitory effect on TGF- $\beta 1$-stimulated PANC-1 cells also increased. Using t-test analysis, the proliferation inhibiting effect of the $10 \mu \mathrm{mol} / \mathrm{ml}$ curcumin-treated group was significantly higher than that of the control group $(\mathrm{P}<0.01)$. The proliferation inhibiting effect of the $20 \mu \mathrm{mol} / \mathrm{ml}$ curcumin-treated group was significantly higher than that of the $10 \mu \mathrm{mol} / \mathrm{ml}$ curcumin-treated and the control group $(\mathrm{P}<0.01$, respectively), and the proliferation inhibiting effect of the $30 \mu \mathrm{mol} / \mathrm{ml}$ curcumin-treated group was also significantly higher than that of the 10 and $20 \mu \mathrm{mol} / \mathrm{ml}$ curcumin-treated and the control group $(\mathrm{P}<0.01$, respectively) as shown in Table I.

Expression level of Shh, GLII, E-cadherin and vimentin in TGF $\beta 1$-stimulated PANC-1 cells. The Hh signaling pathway is abnormally activated in a variety of tumors and is associated with development and invasion, and plays an important role in the transfer process. Hh signaling target genes are related to tumor cell growth, apoptosis, metastasis, EMT. To 
Table II. Apoptosis rate of TGF- $\beta 1$-stimulated PANC- 1 cells treated with curcumin detected by flow cytometery ( $\%$, mean $\pm \mathrm{SD})$.

\begin{tabular}{lc}
\hline Group & Apoptosis rate \\
\hline Control group & $7.62 \pm 0.32$ \\
Curcumin $(10 \mu \mathrm{mol} / \mathrm{ml})^{\mathrm{a}}$ & $9.52 \pm 0.56$ \\
Curcumin $(20 \mu \mathrm{mol} / \mathrm{ml})^{\mathrm{a}, \mathrm{b}}$ & $12.92 \pm 0.67$ \\
Curcumin $(30 \mu \mathrm{mol} / \mathrm{ml})^{\mathrm{a}, \mathrm{b}, \mathrm{c}}$ & $35.57 \pm 1.26$ \\
\hline
\end{tabular}

${ }^{\mathrm{a}} \mathrm{P}<0.01$ vs. control group; ${ }^{\mathrm{b}} \mathrm{P}<0.01$ vs. $10 \mu \mathrm{mol} / \mathrm{ml}$ curcumin group; ${ }^{\mathrm{c}} \mathrm{P}<0.01$ vs. 10 and $20 \mu \mathrm{mol} / \mathrm{ml}$ curcumin group.
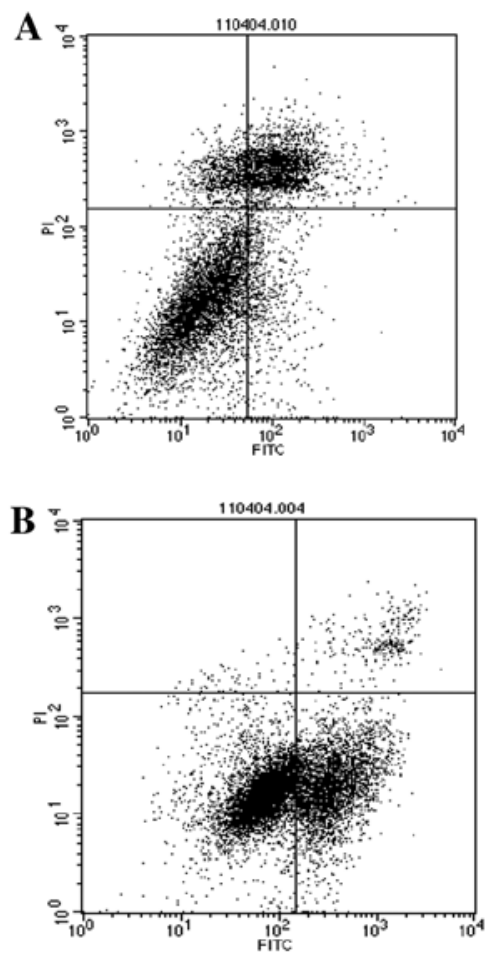

Figure 2. Apoptosis rate of TGF- $\beta 1$-stimulated PANC-1 cells treated with curcumin (\%). (A) Control group; (B) curcumin-treated group (30 $\mu \mathrm{mol} / \mathrm{ml})$.

The experimental results of the flow cytometry also showed that when the curcumin concentration increased, the apoptosis of TGF- $\beta 1$-stimulated PANC-1 cells also increased. With t-test analysis, the apoptosis of the $10 \mu \mathrm{mol} / \mathrm{ml}$ curcumin-treated group was significantly different from that of the control group $(\mathrm{P}<0.01)$. The apoptosis of the $20 \mu \mathrm{mol} / \mathrm{ml}$ curcumin-treated group was significantly different from that of the $10 \mu \mathrm{mol} / \mathrm{ml}$ curcumin-treated and the control group $(\mathrm{P}<0.01$, respectively), and the apoptosis of the $30 \mathrm{~mol} / \mathrm{ml}$ curcumin-treated group was also significantly different from that of the 10 and $20 \mu \mathrm{mol} / \mathrm{ml}$ curcumin-treated and the control group $(\mathrm{P}<0.01$, respectively) as shown in Table II, Fig. 2.

Effects of curcumin on the expression levels of Shh, GLII, E-cadherin and vimentin in TGFB1-stimulated PANC-1 cells. The antitumor mechanism of curcumin is highly complicated and involves several signaling pathways, such as EGFR, HER-2,
A

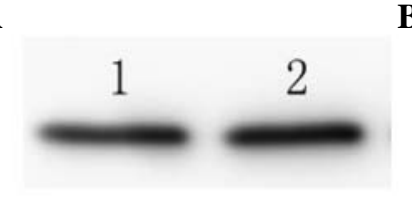

B

C

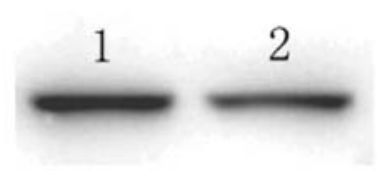

D

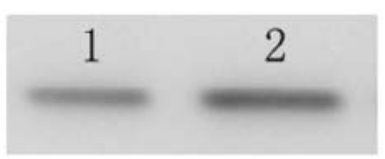

$\mathbf{E}$
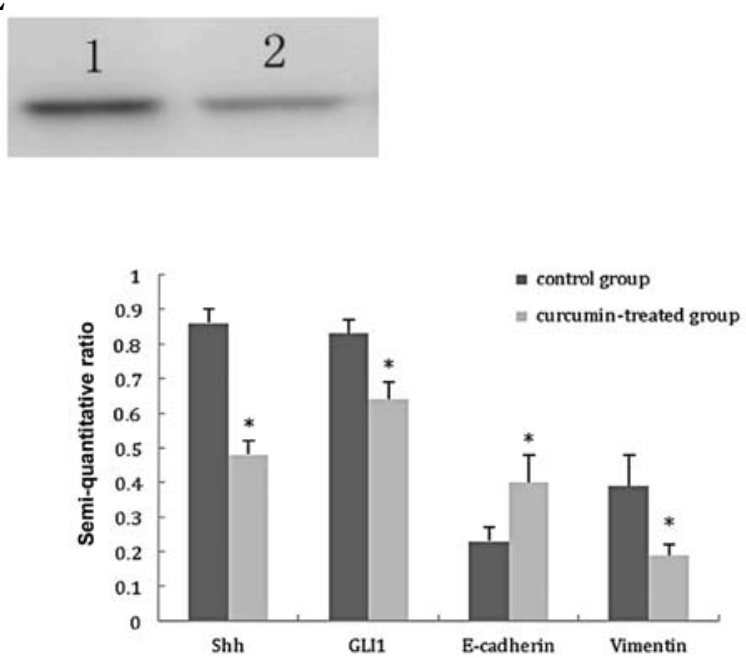

Figure 3. Expression level of Shh, GLI1, E-cadherin and vimentin in TGF- $\beta 1$-stimulated PANC-1 cells treated with curcumin detected by western blot analysis. (A) Internal control: GAPDH; (B) expression level of Shh; (C) expression level of GLI1; (D) expression level of E-cadherin; (E) expression level of vimentin. 1, control group; 2, curcumin-treated group $(30 \mu \mathrm{mol} / \mathrm{ml}) .{ }^{*} \mathrm{P}<0.01$ vs. control group, mean $\pm \mathrm{SD}, \mathrm{n}=5$.

Wnt/ $\beta$-catenin and its downstream signaling molecules ERK, AKT, NF- $\kappa$ B, STATs. In order to investigate whether curcumin is able to reverse the EMT of TGF- $\beta 1$-stimulated PANC- 1 cells by inhibiting the Hh signaling pathway, the TGF- $\beta 1$-stimulated PANC-1 cells were treated with $30 \mu \mathrm{mol} / \mathrm{ml}$ curcumin for $48 \mathrm{~h}$, and the expression levels of Shh, GLI1, vimentin and E-cadherin were then detected by western blot analysis.

Taking GAPDH as internal control, the results were obtained by semi-quantitative analysis of the gray scales of bands using Band Leader software. The results revealed that the expression levels of Shh and GLI1 in the curcumin-treated group were significantly decreased compared with those in the control group $(\mathrm{t}=14.66, \mathrm{P}<0.01 ; \mathrm{t}=7.46, \mathrm{P}<0.01$, respectively), the expression level of E-cadherin in the curcumin-treated group was significantly increased compared with that in the control group $(\mathrm{t}=4.37, \mathrm{P}<0.01)$, and the expression level of vimentin in the curcumin-treated group was also significantly decreased compared with that in the control group $(\mathrm{t}=5.00$, $\mathrm{P}<0.01)$. The results suggest that curcumin inhibits the activation of the Hh signaling pathway and reverses the EMT of TGF- $\beta 1$-stimulated PANC-1 cells, as shown in Fig. 3.

Curcumin inhibits cell invasion and migration of TGF- $\beta 1$ stimulated PANC-1 cells. EMT is defined as particular 
A

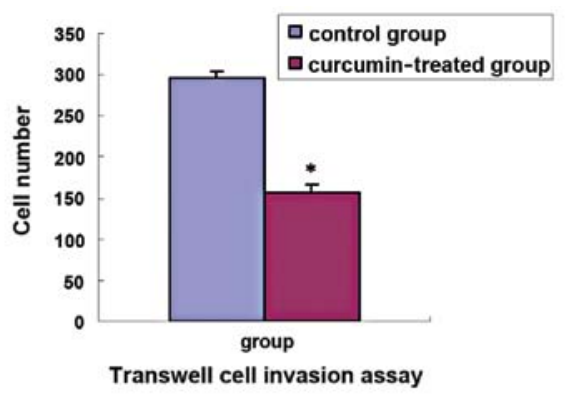

B

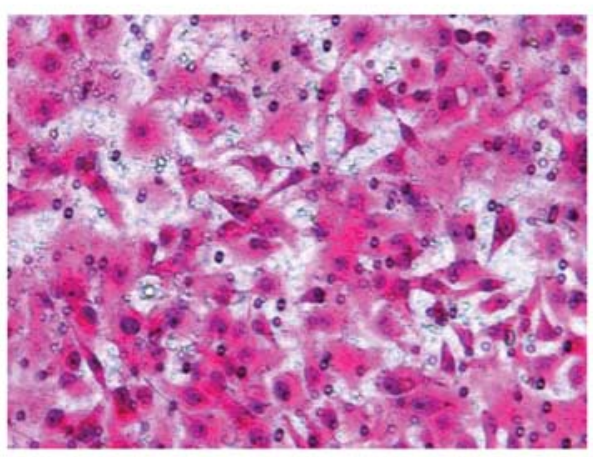

$\mathrm{C}$

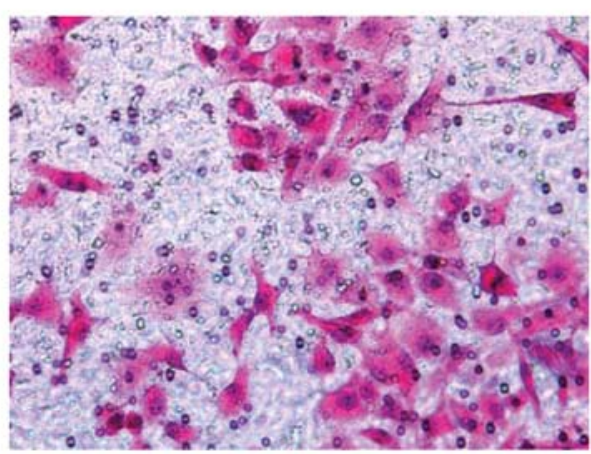

Figure 4. Transwell cell invasion assay of curcumin on TGF- $\beta 1$-stimulated PANC-1 cells. (A) Invasion assay of curcumin on TGF- $\beta 1$-stimulated PANC-1 cells. (B) Images of invasion in the control group (magnification, x200). (C) Images of invasion in the curcumin-treated group (magnification, $\mathrm{x} 200) .{ }^{*} \mathrm{P}<0.01$ vs. control group, mean $\pm \mathrm{SD}, \mathrm{n}=5$. Control group, TGF- $\beta 1$ stimulated PANC-1 cells. Curcumin-treated group, TGF- $\beta 1$-stimulated PANC-1 cells treated with curcumin $(30 \mu \mathrm{mol} / \mathrm{ml})$.

physiological or pathological conditions in which the epithelial cells with polarity lose their polarity and convert into interstitial cells with the ability to move freely in the cell matrix. The tumor cells that acquire EMT phenotype have increased invasion ability and are easy to transfer. To verify whether curcumin can inhibit the metastatic ability of TGF- $\beta 1$-stimulated PANC-1 cells, we performed Transwell cell invasion assay and wound healing assay. The results showed that cell invasion in the curcumin-treated group (30 $\mu \mathrm{mol} / \mathrm{ml}$ ) was significantly decreased compared with that in the control group $(\mathrm{t}=7.68, \mathrm{P}<0.01)$, as shown in Fig. 4A. The scratch wound in the curcumin-treated group healed slower than that in the control group $(\mathrm{t}=12.90, \mathrm{P}<0.01)$, as shown in Fig. 5A. Representative images of invasion and wound healing are shown in Figs. 4B and C, and 5B and C. The results suggest that curcumin inhibits cell invasion and migration of TGF- $\beta 1$ stimulated PANC-1 cells.
A

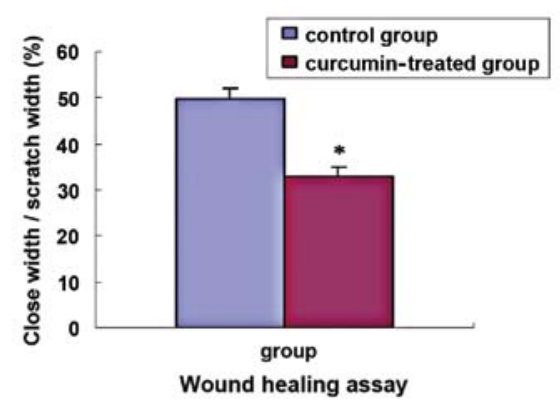

B

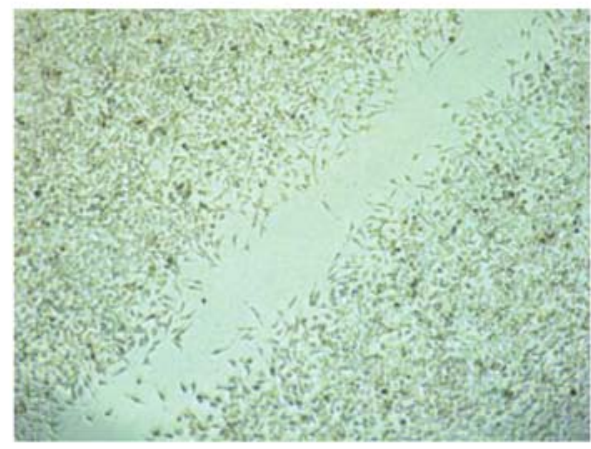

C

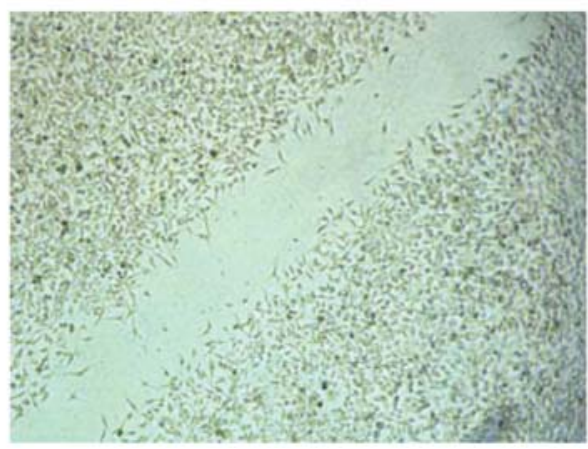

Figure 5. (A) Wound healing assay of curcumin on TGF- $\beta 1$-stimulated PANC-1 cells. (B) Images of wound healing in the control group (magnification, x100). (C) Images of wound healing in the curcumin-treated group (magnification, $\mathrm{x} 100$ ). ${ }^{*} \mathrm{P}<0.01$ vs. control group, mean $\pm \mathrm{SD}, \mathrm{n}=5$. Control group, TGF- $\beta 1$-stimulated PANC-1 cells; curcumin-treated group, TGF- $\beta 1$ stimulated PANC-1 cells treated with curcumin $(30 \mu \mathrm{mol} / \mathrm{ml})$.

\section{Discussion}

Abnormal and sustained activations of several signaling pathways are the main mechanisms of malignant tumor development, invasion, metastasis, recurrence and resistance. Curcumin has chemopreventive and therapeutic roles in a variety of tumor cells, including breast, gastric, colorectal, lung, pancreatic and prostate cancer (12-14). The antitumor mechanism of curcumin is to regulate multiple signaling molecules, such as downregulation of EGFR, HER-2, SHH/GLI1 Wnt/ $\beta$-catenin and its downstream signaling molecules ERK, AKT, NF- $\kappa B$, STATs, and upregulation of $\mathrm{p} 21$, p27, cell cycle kinase inhibitors $(13,15-17)$.

Curcumin can inhibit pancreatic cancer cell proliferation, induce apoptosis, anti-angiogenesis, chemosensitizing, but its mechanism is not yet fully understood. Curcumin may inhibit EGFR, STAT-3, NF- $\mathrm{BB}$ and their downstream target genes, 
multidrug resistance-associated protein 5 expression (18-21). Curcumin inhibits Panc-28 and L3.6pL pancreatic cancer cell proliferation through downregulation of NF- $\mathrm{B}$-dependent genes and Sp1, Sp2, Sp3 transcription factors (18). Curcumin can suppress the transplantation tumor growth of $\mathrm{L} 3.6 \mathrm{pL}$ pancreatic cells in nude mice through intraperitoneal injection (20). Curcumin can improve the antiproliferative effects of gemcitabine on BxPC-3, Panc-1, MIAPaCa-2 pancreatic cancer cells and can induce apoptosis $(19,22)$. In animal models of pancreatic cancer, the combination of curcumin and gemcitabine is more effective than gemcitabine alone in the inhibition of tumor growth and anti-angiogenesis $(18,21)$. The chemotherapy sensitizing effect of curcumin is partly due to the inhibition of the expression of STAT-3 and NF- $\mathrm{B}$ regulated genes such as cyclins, c-Myc, Bcl-2, Bxl-xl, MMPs and VEGF $(18,21)$.

Studies have found that Hh signaling mediated tumor development. The cross-talk between the Hh signaling with other signaling pathways, such as EGFR, Wnt/ $\beta$-catenin and transforming growth factor- $\beta$ (TGF- $\beta$ )/TGF- $\beta$ receptors, also play important roles (23). Morton et al (23) also found that the Hh signaling pathway has a synergistic effect with activated K-ras signaling by reducing tumor cell dependence on sustained activation of MAPK and PI3-K/Akt/mTOR signals, thereby enhancing the K-ras-induced pancreatic cancer development. In pancreatic ductal adenocarcinoma the downstream nuclear transcription factor GLI1 of the Hh signaling pathway is not completely dependent on upstream Shh-Ptch-Smo signals and is also regulated by TGF- $\beta$ and KRAS signals (24).

TGF- $\beta 1$, a multifunctional polypeptide cytokine, has an impact on a variety of cell growth, differentiation, apoptosis and immune regulations. The signaling pathway of TGF- $\beta 1$ is to inhibit epithelial cell growth and to induce apoptosis of epithelial cells. However, it has been found that the majority of tumor cells can secrete TGF- $\beta 1$ by autocrine or paracrine modes. The high level of TGF- $\beta 1$ in the tumor tissue can not only promote the growth of tumor cells, and inhibit apoptosis, but it can also promote the occurrence of EMT. Pancreatic cancer cells secrete TGF- $\beta 1$; the tumor-derived TGF- $\beta 1$ plays an important role in pancreatic cancer microenvironment. miR-23a regulates TGF- $\beta$-induced EMT by suppression of E-cadherin and contributes to EGFR-TKI resistance in lung cancer cells (25).

In our experiment, the proliferation, invasion and migration activities of pancreatic cancer PANC-1 cells increased significantly by stimulation with TGF- $\beta 1(5 \mathrm{ng} / \mathrm{ml})$ for 7 days. The expression levels of Shh and GLI1 increased, E-cadherin decreased, while vimentin expression increased as well. Compared with the control group, the difference was significant. These results indicate that TGF- $\beta 1$ promotes EMT transition of PANC-1 cells.

Subsequently, we treated the TGF- $\beta 1$-stimulated PANC-1 cells with different concentrations of curcumin. We found that with the gradual increase of the concentration of curcumin, the inhibition of cell proliferation also increased, and $30 \mu \mathrm{mol} / \mathrm{ml}$ of curcumin significantly inhibited the proliferation of PANC-1 cells. After the PANC-1 cells were treated with curcumin, the rate of apoptosis was significantly increased. Our experimental results suggest that curcumin inhibits PANC-1 cell proliferation and induces cell apoptosis in vitro.
Following treatment with curcumin, the expression levels of Shh and GLI1 were significantly decreased in TGF- $\beta 1$ stimulated PANC-1 cells. GLI protein is the downstream transcription factor and plays a key role in the Hh pathway. GLI1 is also a target gene of the Hh signal. Our results suggest that curcumin inhibits $\mathrm{Hh}$ signaling in TGF- $\beta 1$-stimulated PANC-1 cells.

The most important changes of EMT are reduced or lost expression of epithelial markers E-cadherin, and elevated expression of interstitial cell markers, such as fibronectin, vimentin $(8,9)$. Our experimental study also found that the expression levels of Shh and GLI1 were significantly decreased, as was the expression of vimentin, while the expression of E-cadherin increased in TGF- $\beta 1$-stimulated PANC-1 cells treated with curcumin. Furthermore, cell invasion significantly decreased, and the scratch wound healed slower in the curcumintreated group. The results suggest that curcumin inhibits the cell invasion and migration of TGF- $\beta 1$-stimulated PANC- 1 cells, and reverses the EMT of TGF- $\beta 1$-stimulated PANC- 1 cells.

These findings suggest that TGF- $\beta 1$ induces the EMT of the pancreatic cancer PANC-1 cells through activation of $\mathrm{Hh}$ signaling. Curcumin inhibits cell proliferation, induces apoptosis, decreases cell invasion and migration, and reverses the EMT of the TGF- $\beta 1$-stimulated PANC-1 cells by inhibiting the Hh signaling pathway.

\section{Acknowledgements}

This study was supported by the Zhejiang Provincial Natural Science Foundation of China (no. Y2100434).

\section{References}

1. Goel A and Aggarwal BB: Curcumin, the golden spice from Indian saffron, is a chemosensitizer and radiosensitizer for tumors and chemoprotector and radioprotector for normal organs. Nutr Cancer 62: 919-930, 2010.

2. Basnet P and Skalko-Basnet N: Curcumin: an anti-inflammatory molecule from a curry spice on the path to cancer treatment. Molecules 16: 4567-4598, 2011.

3. Pirozzi G, Tirino V and Camerlingo R: Epithelial to mesenchymal transition by TGF- $\beta 1$ induction increases stemness characteristics in primary non small cell lung cancer line. PLoS One 6: e21548, 2011.

4. Maitah YM, Ali S, Ahmad A, Gadgeel S and Sarkar FH Up-regulation of sonic hedgehog contributes to TGF- $\beta 1$-induced epithelial to mesenchymal transition in NSCLC cells. PLoS One 6: e16068, 2011.

5. Thomson S, Petti F, Sujka-Kwok I, Mercado P, Bean J, Monaghan M, Seymour SL, Argast GM, Epstein DM and Haley JD: A systems view of epithelial-mesenchymal transition signaling states. Clin Exp Metastasis 28: 137-155, 2011.

6. Uramoto H, Iwata T, Onitsuka T, Shimokawa H, Hanagiri T and Oyama T: Epithelial-mesenchymal transition in EGFR-TKI acquired resistant lung adenocarcinoma. Anticancer Res 30: 2513-2517, 2010.

7. Wells A, Yates $C$ and Shepard CR: E-cadherin as an indicator of mesenchymal to epithelial reverting transitions during the metastatic seeding of disseminated carcinomas. Clin Exp Metastasis 25: 621-628, 2008.

8. Hotz HG, Hotz B and Buhr HJ: Genes associated with epithelialmesenchymal transition: possible therapeutic targets in ductal pancreatic adenocarcinoma? Anticancer Agents Med Chem 11: 448-454, 2011.

9. Dai J, Ai K, Du Y and Chen G: Sonic hedgehog expression correlates with distant metastasis in pancreatic adenocarcinoma. Pancreas 40: 233-236, 2011.

10. Kelleher FC: Hedgehog signaling and therapeutics in pancreatic cancer. Carcinogenesis 32: 445-451, 2011. 
11. Katoh $\mathrm{Y}$ and Katoh M: Hedgehog target genes: mechanisms of carcinogenesis induced by aberrant hedgehog signaling activation. Curr Mol Med 9: 873-886, 2009.

12. Mimeault M and Batra SK: Potential application of curcumin and its novel synthetic analogs and nanotechnology-based formulations in cancer prevention and therapy. Chin Med 23: 31, 2011.

13. Nautiyal J, Banerjee S, Kanwar SS, Yu Y, Patel BB, Sarkar FH and Majumdar AP: Curcumin enhances dasatinib-induced inhibition of growth and transformation of colon cancer cells. Int J Cancer 128: 951-961, 2011.

14. Teiten MH, Gaascht F, Cronauer M, Henry E, Dicato M and Diederich M: Anti-proliferative potential of curcumin in androgen-dependent prostate cancer cells occurs through modulation of the Wingless signaling pathway. Int J Oncol 38: 603-611, 2011.

15. Kunnumakkara AB, Anand $\mathrm{P}$ and Aggarwal BB: Curcumin inhibits proliferation, invasion, angiogenesis and metastasis of different cancers through interaction with multiple cell signaling proteins. Cancer Lett 269: 199-225, 2008.

16. Yallapu MM, Maher DM, Sundram V, Bell MC, Jaggi M and Chauhan SC: Curcumin induces chemo/radio-sensitization in ovarian cancer cells and curcumin nanoparticles inhibit ovarian cancer cell growth. J Ovarian Res 3: 11, 2010.

17. Aggarwal BB, Banerjee S, Bharadwaj U, Sung B, Shishodia $S$ and Sethi G: Curcumin induces the degradation of cyclin E expression through ubiquitin- dependent pathway and up-regulates cyclin-dependent kinase inhibitors p21 and p27 in multiple human tumor cell lines. Biochem Pharmacol 73: 1024 $1032,2007$.

18. Kunnumakkara AB, Guha S, Krishnan S, Diagaradjane P, Gelovani J and Aggarwal BB: Curcumin potentiates antitumor activity of gemcitabine in an orthotopic model of pancreatic cancer through suppression of proliferation, angiogenesis, and inhibition of nuclear factor-kappaB regulated gene products. Cancer Res 67: 3853-3861, 2007.
19. Ali S, Ahmad A, Banerjee S, Padhye S, Dominiak K, Schaffert JM, Wang Z, Philip PA and Sarkar FH: Gemcitabine sensitivity can be induced in pancreatic cancer cells through modulation of miR-200 and miR-21 expression by curcumin or its analogue CDF. Cancer Res 70: 3606-3617, 2010.

20. Jutooru I, Chadalapaka G, Lei P and Safe S: Inhibition of NFkappaB and pancreatic cancer cell and tumor growth by curcumin is dependent on specificity protein down-regulation. J Biol Chem 285: 25332-25344, 2010.

21. Ramachandran C, Resek AP, Escalon E, Aviram A and Melnick SJ: Potentiation of gemcitabine by Turmeric Force ${ }^{\mathrm{TM}}$ in pancreatic cancer cell lines. Oncol Rep 23: 1529-1535, 2010.

22. Mimeault $M$ and Batra SK: Frequent deregulations in the hedgehog signaling network and cross-talks with the epidermal growth factor receptor pathway involved in cancer progression and targeted therapies. Pharmacol Rev 62: 497-524, 2010.

23. Morton JP, Mongeau ME, Klimstra DS, Morris JP, Lee YC, Kawaguchi Y, Wright CV, Hebrok M and Lewis BC: Sonic hedgehog acts at multiple stages during pancreatic tumorigenesis. Proc Natl Acad Sci USA 104: 5103-5108, 2007.

24. Nolan-Stevaux O, Lau J, Truitt ML, Chu GC, Hebrok M, Fernandez-Zapico ME and Hanahan D: GLII is regulated through Smoothened-independent mechanisms in neoplastic pancreatic ducts and mediates PDAC cell survival and transformation. Genes Dev 23: 24-36, 2009.

25. Cao M, Seike M, Soeno C, Mizutani H, Kitamurak, Minegishi Y, Noro R, Yoshimura A, Cai L and Gemma A: MiR-23a regulates TGF- $\beta$-induced epithelial-mesenchymal transition by targeting E-cadherin in lung cancer cells. Int $\mathrm{J}$ Oncol 41: 865-875, 2012. 